Article

\title{
Internal migration and public opinion about the European Union: a time series cross-sectional study
}

\author{
Anne-Marie Jeannet* \\ Roentgen 1, 20136, Milan, Italy \\ *Correspondence: annemarie.jeannet@unibocconi.it
}

Dondena Centre for Research on Social Dynamics and Public Policy, Bocconi University, Via

\begin{abstract}
Although the European Union (EU) allows citizens from member countries to migrate freely within its confines to facilitate integration, it may be alienating public support for Europe. This article investigates this by extending group threat theory to explain how internal migration is related to public opinion about the EU using annual Eurobarometer data from 1998 to 2014 across 15 Western European countries. Employing a pooled time cross-sectional design, I find that the presence of EU citizens from Central and Eastern European member states is positively related to public beliefs that EU membership is not beneficial for their country. The results also show that this relationship is even stronger during an economic downturn. There is weak evidence that it may be related to distrust in European institutions as well. These findings shed light on why public support for the EU can erode over time and how it responds to contextual changes in Europe's internal migration patterns. The study concludes by discussing how group threat theory is relevant for understanding public opinion about the EU.
\end{abstract}

Key words: public opinion, European Union, EU attitudes, immigration

JEL classification: F6, D72, J15

\section{Introduction}

Lately, the European Union (EU)'s internal migration, a central principle of the community acquis, has come under political scrutiny. There is a strong political imperative for the nation state to manage migration (Huysmans, 2000), which is at odds with the EU's borderless mobility in the Single Market. These public sentiments have had momentous political consequences. Internal migration from European member countries was the main reason that 


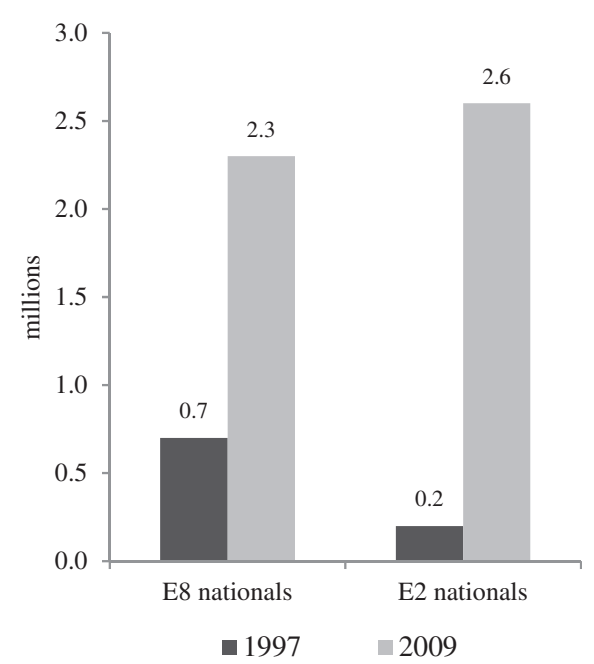

Figure 1. E8 and E2 nationals living in Western European member states (EU-15), 1997 vs. 2009. Author's own analysis, data from Eurostat 'Population country of citizenship' [migr_pop1ctz] extracted 19 October 2015; OECD, Stock of foreign population by nationality extracted 21 October 2015.

voters cast their ballot to leave the EU in Britain's 2016 referendum, which has now resulted in the so-called 'Brexit' (Ipsos MORI, 2016). Recent events suggest that this phenomenon goes beyond Britain: elections in Europe show growing support for right-wing parties with both anti-EU and anti-immigration platforms (Golder, 2016).

The rising political salience of the EU's internal migration has coincided with two accessions along its expansive and populous eastern periphery. The first of these enlargements, in 2004, was the EU's largest accession ever, both in terms of the number of countries and the size of the population. The expansion granted European citizenship to approximately 75 million Central and Eastern European (CEE) nationals from Estonia, Latvia, Lithuania, Poland, Czech Republic, Slovakia, Hungary and Slovenia. ${ }^{1}$ Another accession followed in 2007 when Bulgaria and Romania became member states, adding approximately 30 million people.

Economic disparity between the two regions and decades of suppressed migration potential under communist regimes caused a large-scale migration from Eastern to Western European member countries after the accession. Some Western European member countries enacted temporary restrictions on the labour market participation of new European citizens, but, while these restrictions did divert flows to a certain extent (Boeri and Brücker, 2005), they were not a safeguard against inflows (Steinhardt, 2009). As shown in Figure 1, from 1997 to 2009, the number of Europeans from new Central and Eastern member countries living in Western Europe grew by about 4 million, coinciding with Europe's economic crisis.

The Central and Eastern Europeans who moved to Western European member countries have not been warmly welcomed. While European citizens have rights to the labour market, family reunification and welfare state resources, the public does not 'treat EU citizens with

1 Malta and Cyprus also joined in 2004. 
any degree of privilege compared to migrants from outside the EU' (McLaren, 2001, p. 102; Sniderman et al., 2002). Solidarity between Europe's core and periphery has developed more slowly than economic integration (Scheuer and Schmitt, 2009) and East-West internal migration highlighted tensions about mobility. Across Western Europe, many oppose immigration from poorer European countries (Gorodzeisky, 2011). For instance, Ford (2011) finds that Eastern Europeans are the most opposed of all 'white' immigrant groups in the UK.

Although the EU allows citizens from new member countries to migrate within the region to facilitate integration, it has been suggested that this may be, paradoxically, alienating public support for Europe (Toshkov and Kortenska, 2015). The paradox lies in the fact that the further European institutions become integrated, the more public support for the EU dwindles. If this is the case, it is an undesired and inadvertent consequence: political elites have aimed to use institutional integration as a vehicle for fostering the 'European identification of we-feelings' (Scheuer, 1999, p. 30).

The existing literature has considerably advanced our understanding of the antecedents of individual-level attitudes towards Europe. This body of work has increasingly emphasizing the importance of socio-tropic or group interest (McLaren, 2007; Garry and Tilley, 2009) and non-material factors such as cultural threat (McLaren, 2002) and identity (Carey, 2002; Hooghe and Marks, 2004). Without disputing this body of knowledge, I contend that public opinion research has largely ignored the consequences of internal migration patterns for European attitudes. ${ }^{2}$ Understanding its impact is crucial, since public opinion influences political representation and decision-making (Stimson, 1999; Taber, 2003), and public support is critical to maintaining democratic legitimacy (Almond and Verba, 1965), and a lack thereof can constrain for further European integration (Hooghe and Marks, 2009; Hobolt and Vries, 2016).

The contribution of this article is two-fold. First, it sets out to answer the open empirical question about what explains cross-national differences in public opinion about the EU and their changes over time. Second, it draws on group threat theory as a framework to investigate if a rise of internal migration from new member countries that joined in the 2004/7 enlargements has contributed to the rise of anti-EU sentiment in member countries. I argue that negative sentiments by provoking competition between Western Europeans and new EU citizens and internal migration prompts the public in a host country to react defensively against the EU. Another novel aspect to this article is that it studies mass public opinion in a comparative setting unlike existing work that tends to to be single country studies. I exploit the variation in migration after the Eastern enlargements to observe how it relates to EU support in 15 different Western European mass publics over time.

\section{Theoretical expectations}

\subsection{Mass attitudes towards the EU}

In this study, I am interested in two different mass attitudes towards the EU. First is a sociotropic utilitarian attitude towards EU membership. Attitudes towards Europe have been noted for their socio-tropical basis (Carrubba, 2001; Kaltenthaler and Anderson, 2001), and parallels may be drawn with the self-interest utilitarian attitudes (Anderson and

2 Notable exceptions include Lahav (2004) and McLaren (2001, 2006). 
Reichert, 1995; Gabel and Palmer, 1995), because it shares the notion of support for Europe as an instrumental calculation of costs and benefits. The distinction is that a utilitarian socio-tropic attitude refers to the way in which the citizenry weighs the benefits of EU membership on the basis of the perceived interests for their country rather than for themselves.

However, a socio-tropic orientation is not only economically motivated, and this brings us to the second form of mass attitude that is of interest in this study: the public's political distrust in the EU. Mass political distrust in the EU can be defined as a shared perception that the EU is producing outcomes inconsistent with collective expectations (Hetherington, 2004, p. 9) and that a country's interests would not be attended to 'if the authorities were exposed to little supervision or scrutiny' (Easton, 1957, p. 447). This attitude conceives of the public's connection with the idea of Europe as based on ideals rather than an economic calculus, as scholars have tended to emphasize the importance of identity and affective support (Klingeren et al., 2013).

\subsection{Internal migration and public opinion the EU}

Group threat theory postulates that group competition over resources provokes in-groups to perceive out-groups as a threat to their own interest (Blalock, 1967). The presence of foreigners in a host country provokes a collective socio-tropic threat, whereby an in-group is threatened by the presence of the out-group (Blumer, 1958; Quillian, 1995), which is understood 'in terms of general societal, rather than personal costs and benefits' (Sears and Funk, 1990, p. 15). In other words, in-groups compete with newcomers for economic resources, because they are motivated to preserve their own group's material interest. Thus, foreigners who settle in a host country are seen as threatening the jobs of locals (Hollifield et al., 2014) and usurping the country's welfare resources (Citrin et al., 1997) of which they are perceived to be 'undeserving' (Oorschot, 2000).

The formation of in-groups and out-groups is based on social identity, which is derived from self-defined group membership. In-groups, then, are hard-wired to differentiate and protect themselves from out-groups (Tajfel, 1982). In modern democracies, national identity is central to a sense of belonging (Anderson, 1983; Gellner, 1983) and, in Europe, linguistic and cultural traditions often form an affective political identification with the nation (Duchesne and Frognier, 1994). While Europeans are capable of holding both national and supranational identities simultaneously (Risse, 2003; Risse, 2014), national identities still remain more salient (Carey, 2002).

McLaren (2006) has been instrumental in suggesting that group threat theory may hold explanatory power as to why certain individuals have anti-European sentiments. McLaren argues that fear of 'the degradation of the resources of the nation' and hostility to other cultures are crucial, finding that citizens who hold anti-immigration attitudes tend also to have negative attitudes towards the EU (McLaren, 2002, 2006, p. 55), which has been confirmed by others (de Vreese and Boomgaarden, 2005; Boomgaarden et al., 2011; Beaudonnet and Barbulescu, 2014).

So, can the explanatory power of group threat theory be extended to also claim that the size of the foreign population explains the cross-national variation in public support for the EU across time and space? Thus far, its application to mass EU attitudes remains understudied and not well understood. ${ }^{3}$ Studies of individual-level attitudes suggest a link between

3 This has been extensively studied regarding anti-immigrant attitudes (see Ceobanu and Escandell 2010). 
perceived immigration and the likelihood that a person has negative sentiments towards European integration (Luedtke, 2005). According to some, this occurs because citizens blame extra-European immigration on the EU (Kumlin, 2009, 2011; Hobolt and Tilley, 2014). Yet, other studies do not find a relationship between the actual size of the foreign population and individual attitudes towards the EU (Klingeren et al., 2013; Beaudonnet and Barbulescu, 2014).

I contend that, while group threat theory may not necessarily predict patterns of individual attitudes about the EU, it may explain why certain some publics in EU member countries are less supportive of the EU and how this changes over time. This is because the removal of borders between European countries has brought about further internal migration and, by provoking a sense of socio-tropic group threat, may be reflected in negative public opinion towards the EU. Moreover, public opinion may also differentiate grievances regarding internal EU migration from those regarding external EU migration (which is ostensibly still under control of national governments). Initial evidence provides support for this line of reasoning and indicates that this public reaction is largely provoked by migration from new European member countries. A recent study finds evidence of the negative relationship between the presence of Central and Eastern Europeans and regional-level support for European integration in three of four countries studied (Toshkov and Kortenska, 2015). I take this idea further and hypothesize the following:

Hypothesis 1: A greater presence of Central and Eastern European citizens living in a Western European country is associated with a greater public concern about whether their country benefits from European membership.

There is also a reason to ask ourselves if internal migration within Europe may sow seeds of distrust in the EU by raising fundamental doubts about the European project. Sentiments of political distrust can arise when there is a perception that governing institutions are not adequately protecting a community 'from the potentially major changes to cultural composition and economic competition that they perceive are likely to result from large scale immigration' (McLaren, 2012, p. 207). Internal migration is a dual representation of two salient political symbols: immigration and the EU (McLaren, 2002, 2004), which are often linked in the mass media. The media plays a crucial role in how the public makes sense of complex phenomena such as migration (Blinder and Jeannet, 2018) and attributes political blame (Shaver, 1985). Moreover, media frames exert an influence on the public's opinion about the EU and its institutions, particularly for issues related to migration in the EU (van Klingeren et al., 2017). Thus, I also hypothesize that internal EU migration from new member countries may raise the public's doubts about the EU as a political system.

Hypothesis 2: A greater presence of Central and Eastern European citizens living in a Western European country is associated with a greater public distrust in European political institutions.

\section{The conditional impact of economic scarcity}

Group threat theory postulates that economic conditions have a crucial influence on intergroup relations, and thus, economic scarcity is a mechanism that exacerbates conflict between citizens and foreigners (Olzak, 1992; Dancygier, 2010). According to group threat theory, in-groups compete with out-groups over resources, implying that the extent of 
competition between these groups is driven by two forces: not only the size of the foreign population (the number of competitors but also the extent of economic resources in the society. Even if immigration can bring economic benefits to the host country, the public tends to believe that immigration occurs in zero-sum competitive situations whereby a gain for the out-group is perceived to automatically imply a loss for the in-group (Bobo and Hutchings, 1996).

In addition to group-oriented materialistic reactions, the economic context also conditions the symbolic and affective aspects of inter-group relations, since economic scarcity can give rise to in-group favoritism and reinforce out-group hostility (Filindra and PearsonMerkowitz, 2013; Chang et al., 2016) by propagating a rivalry between the groups. In fact, evidence shows that publics in immigrant-receiving countries tend to adopt more defensive attitudes about immigrants and immigration during times of economic difficulty (Quillian, 1995; Dancygier and Donnelly, 2013; Polavieja, 2016).

So, how might economic scarcity condition the relationship between internal migration and public opinion about the EU? I argue that economic scarcity, by fuelling group rivalry between Western Europeans and new EU citizens who move to live and work in Western Europe, would then be expected to heighten the public's defensive reaction to internal migration, and this would have consequences for attitudes towards Europe. It has been established that macro-economic factors condition public opinion about European integration (Anderson, 1998; Gabel, 1998) and that should not be surprising, since elites have framed EU membership around an economic calculus (Hooghe and Marks, 2005). Moreover, during times of economic difficulty, political trust is eroded (Bovens and Wille, 2008), and national elites also tend to shield themselves by deflecting blame to the supranational level (Vasilopoulou et al., 2014; Schlipphak and Treib, 2017). On the basis of this evidence and the tenets of group threat theory, I put forward two additional hypotheses for testing:

Hypothesis 3: The positive relationship between internal migration from new European countries and public concerns about the country's benefit from EU membership in Western European countries is more acute when macro-economic conditions are poor.

Hypothesis 4: The positive relationship between internal migration from new European countries and public distrust in European institutions in Western European countries is more acute when macro-economic conditions are poor.

\section{Data, measures and methods}

\subsection{Data}

I test my claims with time-series cross-sectional (TSCS) data from 15 Western European countries from 1998 to $2014 .{ }^{4}$ To assess the changes in mass attitudes towards the EU over time, I use pooled annual Eurobarometer (EB) data, ${ }^{5}$ which has the advantage of allowing for the observation of temporal and cross-national variations. Each annual survey interviews approximately between 1000 and 1500 respondents per member country (with the

4 These countries are Austria, Belgium, Denmark, Finland, France, Germany, Greece, Ireland, Italy, Luxembourg, Netherlands, Portugal, Spain, Sweden and the United Kingdom.

5 The data have been pooled by the author using EB waves 53.0, 55.1, 59.1, 61.0, 63.4, 65.2, 67.2, 69.2, $71.1,73.4,75.3,77.3,79.5$. and 82.4. 
exception of Luxembourg) providing a total of 372941 respondents over the entire period. The descriptive statistics and further information about data sources are available in Supplementary Appendix A.

The time period has been selected for both substantive motivations and practical constraints. It spans from before the first eastern accession in 2004 through the lifting of the last restrictions in Western Europe on the freedom of movement of workers from Bulgaria and Romania in 2014. The EB survey goes back to 1974, but the longevity of the survey cannot be fully exploited in this study, since migration data are not available for the full period.

\subsection{Measures}

I consider two measures to gauge mass opinion towards Europe. ${ }^{6}$ The first operationalizes the socio-tropic utilitarian dimension of public opinion. This item, membership disadvantageous, captures the public's opinion about whether or not membership in the EU is beneficial to their country. ${ }^{7}$ The values have been aggregated by calculating the mean response for that country in that given year. In other words, the value represents the percentage of the national public who feel that EU membership is not beneficial to their country.

Next, I measure aggregate distrust in the EU, EU distrust, as an index of five survey items. These are distrust of: the European Commission, the Parliament, the Council of Ministers, the European Central Bank and the European Court of Justice (Cronbach's alpha $=0.91) .{ }^{8}$ Higher values on this index indicate a greater distrust in European institutions, and lower values indicate a lesser distrust. The mean index value is then computed for each country in each year. I opt not to add membership disadvantageous to the index also, as this would lower to the Cronbach's alpha to 0.7. Moreover, there is insufficient theoretical justification, since the two attitudes are conceptually distinct. While one addresses the output-oriented utilitarian dimension, the other addresses the input-oriented affective dimension of European support (Boomgaarden et al., 2011). ${ }^{9}$

To maximize comparability over time, these two measures have been derived from survey instruments that maintain the same wording and response categories in each standard EB. To minimize issues of systematic error that can arise with EB questions (Höpner and Jurczyk, 2015), these measures have also been selected, because they are relatively simply worded, avoid hypothetical or leading questions and do not require highly specialized knowledge about the EU. Nevertheless, other limitations of the standard EB still stand such as the use of multi-stage random sampling rather than pure random sampling and employing back-translation that places emphasis on literal translation rather than functional

6 I am restricted to survey items that are featured annually and where questions and responses have remained unchanged on the standard EB.

7 'Generally speaking do you think that (our country's) membership of the European Union is...?' The survey item has three answer categories: (a) a good thing, (b) a bad thing or (c) neither good nor bad. I recoded the third answer category with the 'don't know' responses (16\%), which are omitted through listwise deletion.

8 'And now for each of the following European institutions, please tell me if you tend to trust it or tend not to trust it?' The survey item has three response categories: (a) tend to trust it, (b) do not tend to trust it and (c) don't know. I recoded the 'don't know' responses as missing, and they are omitted through listwise deletion.

9 As a check, I ran the results when combining the two measures into a single generalized measure of European support, and the results are consistent with those presented here. 


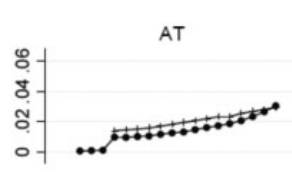

ES

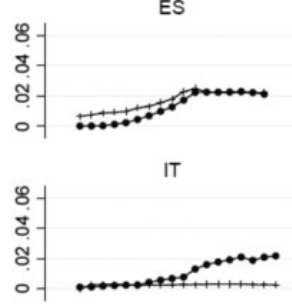

UK

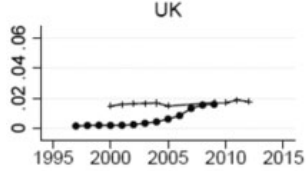

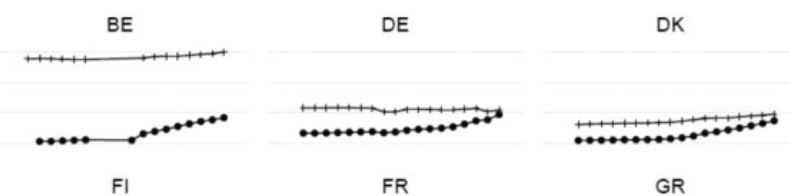

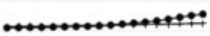

NL

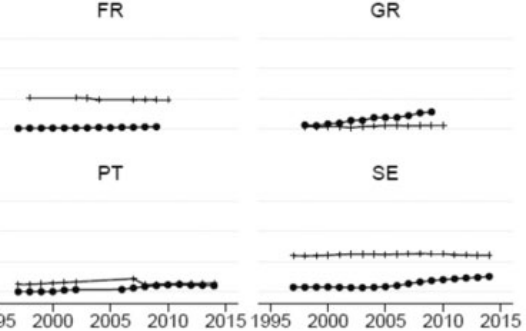

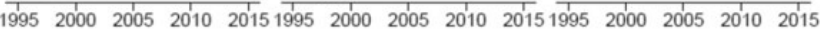

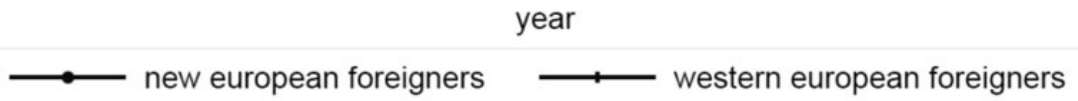

Figure 2. European foreigners as a proportion of total population, 1999-2014. Author's own analysis, data from Eurostat 'Population country of citizenship' [migr_pop1ctz] extracted 19 October 2015; OECD, Stock of foreign population by nationality extracted 21 October 2015.

equivalence (Nissen, 2014). ${ }^{10}$ Another issue is that EB response categories tend to be binary, meaning that individuals who possess neutral opinions tend to respond that they 'don't know'. For this reason, I check that the results presented are consistent with alternative models where the 'don't know' responses are randomly allocated to the binary categories. Those results can be found in Supplementary Appendix B.

The independent variable is the stock of nationals of new European member countries, which is provided by Eurostat ${ }^{11}$ in the form of a proportion of the total population in that country in that year. As we observe in Figure 2, with the exception of France and Portugal, all Western European countries experienced an increase in the proportion of new European citizens, with varying degrees of sharpness.

10 To verify the EB data, I examine the association between aggregate values of distrust in EU institutions with a similar instrument from the European Social Survey (2002-2014 biannual rounds) and find that the two measures are highly correlated. Results are available upon request.

11 Eurostat 2015 ('Population country of citizenship' [migr_pop1ctz] extracted 19-10-15). For countryyears where data are not available from Eurostat, I use data from the OECD 2015 (Stock of foreign population by nationality extracted 21-10-15). As a check, I compare the ratio of Eurostat estimates to OECD estimates for four countries (Germany, Sweden, Spain and Finland) of which we have full information from both data sources and find that this ratio ranges from 1.03 to 0.91 . In the remaining rare cases, I use data from the European Labor Force Survey provided by Holland et al. (2010), which is highly correlated with Eurostat data. Further details are available in the Supplementary Appendix. 
Another important concern is the availability and quality of migration data. For the purposes of this study, foreign stock measures are a more convenient and reliable measure across countries than immigration inflows, because what constitutes immigration is not uniformly defined, and records of migration tend to represent the legal or immigration policy framework of the country and do not adhere to international standardizations. The advantage of using a foreign stock measure is that the criteria remain uniform across all countries and over time. There are two ways to measure the stock of the foreign population: the size of the foreign national population or the size of the foreign-born population. For convenience purposes, I use the former, ${ }^{12}$ because it is more complete and minimizes gaps in the data. ${ }^{13}$ The foreign national population may include not only individuals who are born abroad and who retained the nationality of their country of origin but also includes secondand third-generation foreigners who are born in the host country.

The measure still has some drawbacks, which I have attempted to mitigate through data verification. First, Eurostat and OECD data are composed of estimates that are gathered differently in each country, obtained either from population registers, residence permit data, censuses or special surveys. ${ }^{14}$ Second, the size of the foreign national population can change owing to other factors than migration flows, such as natural increases in the foreign population and legislation on naturalization. ${ }^{15}$ Finally, as with all official migration data, it tends to underestimate foreigners less likely to be registered for census purposes or that do not live in private households such as those who are undocumented or migrate seasonally.

To assess the moderating influence of macro-economic conditions, I use two measures of economic performance that are each interacted with the stock of nationals from new member countries. These are: the country's GDP per capita (EUR) and the national unemployment rate.

I also take into consideration mitigating factors that influence public attitudes towards the EU across countries over time. Two variables are introduced to control for other migration trends that occur contemporaneously. The first is the percentage of third-country (nonEU) nationals as a percentage of the country's total population. The second is the number of Western European nationals as a proportion of the country's total population. Finally, intra-European trade (exports + imports) as a proportion of total trade (exports + imports) is included as a control variable.

\subsection{Estimation strategy}

The data are an unbalanced TSCS including 15 countries over 17 years. Table 1 presents the countries included in the sample along with their longitudinal coverage. Gaps in longitudinal coverage are either because the country did not participate in the EB survey or that estimates of the foreign populations were not available for that year. Since the measures for

12 For a discussion of the differences between foreign national and foreign born measures, see Fassmann (2009).

13 Although gaps are minimized, the data are still not complete for all country-years. See Supplementary Appendix for details.

14 To verify the data, I examine the association between Eurostat data and estimates from the European Labor Force Survey for overlapping years (2004-2014) and find that estimates of the new European populations living in Western Europe are strongly correlated (0.92).

15 Among the countries where both measures are available, I find that measures of the stock of foreign born and foreign nationals from new member countries are strongly correlated (0.96). 
Table 1. Time-series coverage by country

\begin{tabular}{ll}
\hline Country & Years $^{\dagger}$ \\
\hline Austria & $2003,2005-2014$ \\
Belgium & $1999-2002,2007-2014$ \\
Denmark & $1998-2014$ \\
Finland & $1998-2014$ \\
France & $2002,2004,2007-2009$ \\
Germany & $1998-2014$ \\
Greece & $1999-2009$ \\
Ireland & $2006-2014$ \\
Italy & $1998-2014$ \\
Netherlands & $1998-2014$ \\
Portugal & $1998-2002,2007-2014$ \\
Spain & $1998-2013$ \\
Sweden & $1998-2014$ \\
United Kingdom & $2001-2005,2009$ \\
\hline
\end{tabular}

${ }^{\dagger}$ Survey items for mistrust are not available in 1998 or 1999.

membership disadvantageous are not available in 2012, these have been interpolated. To address concerns regarding the TSCS research design, such as small sample sizes and the effect of outlier countries, the results will be subjected to a series of robustness tests.

I report the results for two different estimations. ${ }^{16}$ First, I report the results of a fixed effects (FE) model specified without adjustments for autocorrelation or panel-specific heteroscedasticity. Since Wald tests showed a significant amount of panel-specific heteroscedasticity, I then report the results of a series of ordinary least squares (OLS) regression analysis, which are estimated with panel-corrected standard errors (PSCE). PSCEs are used to adjust for group-wise heteroskedastic error terms, which are common in TSCS data, where error terms have different variances between different units and are correlated across units (Beck and Katz, 1995, 1996). ${ }^{17}$ Following convention, I lag all independent variables and control variables by 1 year. I use country dummies to account for any unobserved time invariant characteristics of countries not included in the model such as historical experiences with migration, cultural orientations, citizenship policies and tenure in the EU. Year dummies are also included to control for any unobserved time shocks and trends such as the gradual improvement in public awareness of European institutions over time.

Woolridge tests reveal that there is no serial correlation when predicting membership disadvantageous but that there is first-order serial correlation when predicting EU distrust. In other words, any distrust that the public held about the EU in the past matters to the extent that it trusts its institutions today. Therefore, in those models that predict EU distrust, I also specify a model with a lagged dependent variable.

16 Results were estimated using Stata 14. The author has made Stata do-files available as supplemental information.

17 Owing to the small $n$ and $T$, tests of stationarity are not conducted (Hadri, 2000). 


\section{Results}

\subsection{Internal migration and mass support for EU membership}

I begin by examining the relationship between internal migration from new member countries and collective support for the country's membership in the EU. Table 2 displays a series of regressions that examine how internal migration from new member countries is related to the public perception that European membership as disadvantageous to their country (membership disadvantageous). Regressions are estimated with both FE models and OLS models with PCSE, producing similar results. The results support Hypothesis 1: larger shares of citizens from new member countries are associated with a higher proportion of the public who feel that EU membership is not benefiting their country. In the FE estimation in Model 1 and the OLS-PSCE estimations in Models 2 and 3, the coefficients for new Europeans are positive and significant, with a moderate coefficient size that is approximately half of a standard deviation of membership disadvantageous. It is also noteworthy the coefficients for Western Europeans and third-country nationals that do not have a significant association.

I further examine the nature of the relationship by specifying two additional models (Models 4 and 5), which introduce an interaction term between macro-economic conditions and the presence of new European citizens. These interaction terms allow me to examine the relationship between internal migration and support for the country's EU membership as economic resources become scarce. Table 2 makes clear that, as expected in Hypothesis 3, conditions of economic scarcity accentuates the negative relationship between internal migration from new member countries and EU membership support. In Model 4, when the proportion of new Europeans is interacted with the level of unemployment, the coefficient for the interaction is positive and significant, while the main effect remains positive, of moderate effect size and statistically significant. Using these, I then illustrate the relationship between these two variables for different levels of unemployment. Figure 3 shows the coefficients and the upper and lower bounds of $95 \%$ confidence intervals for the effects of new Europeans conditional on these different levels of unemployment. The results are significant for all levels of unemployment observed in the sample (0-25\% unemployment rates). Consistent with the expectations, higher levels of new Europeans living in the country are associated with higher proportions of the public believing that EU membership disadvantages their country, especially when domestic unemployment rates are high.

The results in Model 5, when the proportion of new Europeans is interacted with level of GDP per capita, also support the conditional effect of economic scarcity. The coefficient for the interaction term is negative and significant, meaning that the positive and significant association between internal migration and the public's support for membership in the EU is dampened when levels of GDP per capita are higher. As is illustrated in Figure 4, this is significant for all levels of GDP per capita which are observed in the sample. In other words, the effect of new Europeans on membership support is more acute in national contexts where GDP per capita is lower (ceteris paribus).

Turning now to a substantive interpretation of these results, I can say that, all else being equal, an increase of a percentage point in the proportion of new European citizens in the population is associated with an increase of 7.4 points in the percentage of the population who feel that EU membership is not beneficial to their country. The positive relationship is stronger as economic resources become more scarce: when the unemployment rate is greater than $10 \%$, this coefficient is more than $8 \%$ points (which is equivalent to more than half of 


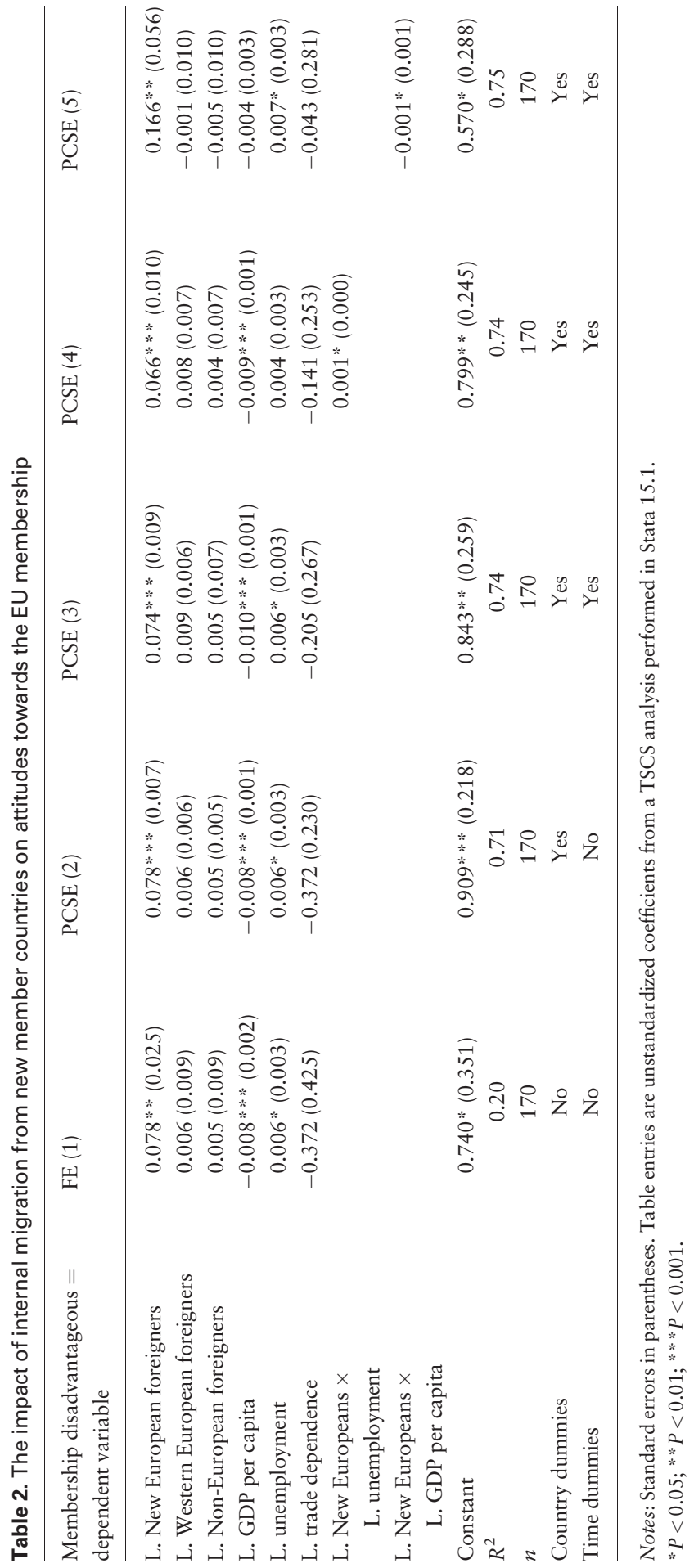




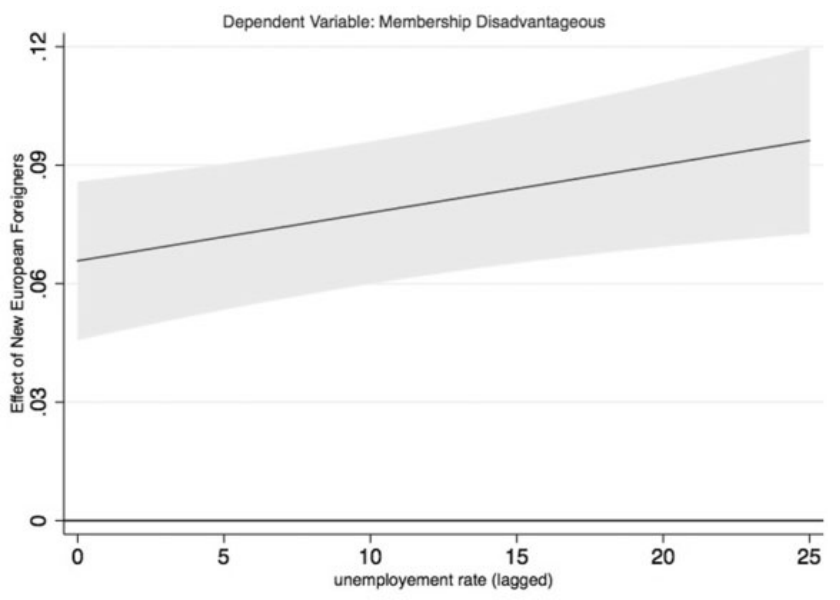

Figure 3. Effect of New European foreigners conditioned on levels of unemployment. 95\% Confidence intervals. OLS-PCSE estimation.

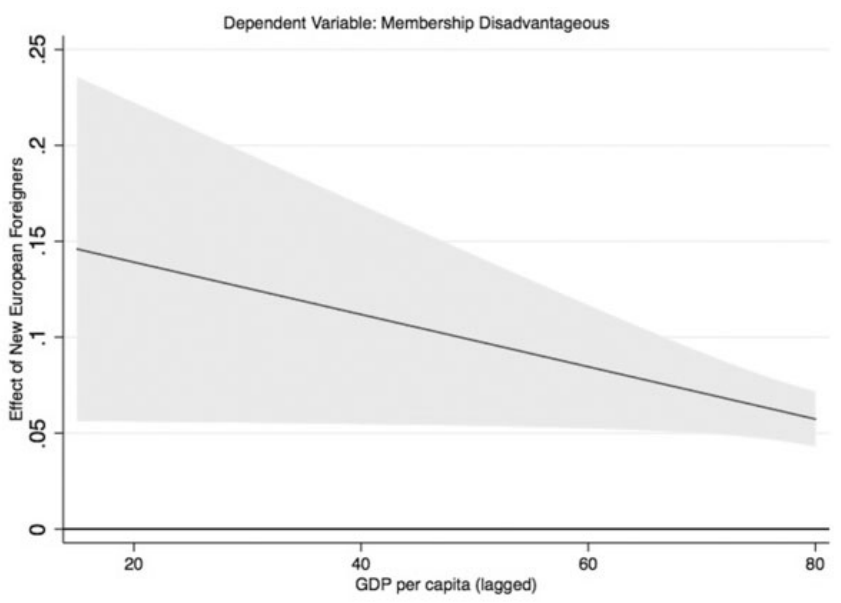

Figure 4. Effect of New European foreigners conditioned on levels of GDP. 95\% Confidence intervals. OLS-PCSE estimation with $\mathrm{AR}(1)$ correction.

a standard deviation) and is more than a ten point increase when GDP per capita is less than 40, 000 Euros. In other words, the negative relationship between internal migration from Central and Eastern member countries and Western Europe's support for EU membership Europe is stronger when the domestic economy fares poorly. In substantive terms, this is an important finding considering that an increase of $1 \%$ point in the proportion of new European citizens in the total population is not an unreasonable scenario: about two-thirds of the Western European countries experienced increases of $1 \%$ point or more during the period examined. 


\subsection{Internal migration and mass distrust in the EU}

In Table 3, I now examine the role of internal migration from new member countries in explaining public distrust in European institutions. In line with our expectations, the coefficient for new European citizens is positive and significant when estimated using FE regression in Model 1 as well when using OLS with PCSE and country dummies in Model 2. The coefficient continues to be highly significant in Model 3 when introducing year dummies, albeit the size of the coefficient is small and less than a quarter of a standard deviation. The size is further diminished and the standard errors are larger in Model 4 when introducing a lagged dependent variable to adjust for the serial correlation in public distrust yet it remains statistically significant. The results in the first four models in Table 3 indicate that a higher level of internal migration from new member countries is accompanied by a greater public distrust in European institutions.

There is evidence that this relationship is conditional on the level of unemployment in the host country. In Model 5, the proportion of new European citizens is interacted with the unemployment rate in the host country, and the coefficient is highly significant and positive while the main effect is diminished and its statistical significance falls below $P<0.05$. Figure 5 provides an illustration of the coefficients and how this varies depending on the level of unemployment. I observe that below $7 \%$ unemployment, the level of unemployment does not have a significant effect on the relationship. Yet when the domestic unemployment rate is higher than $7.5 \%$, the positive influence of new European citizens living in the country on distrust becomes more acute as unemployment increases. Still, this is only partial support for Hypothesis 4 since there is no evidence that the relationship is conditional on GDP per capita. Model 6 shows that the interaction between new Europeans and GDP per capita is not significant and including it into the model does not improve the model fit as measured by the R-squared.

In substantive terms, Model 4 tells us that an increase of new Europeans in the population by $1 \%$ point would result in an increase of 0.019 points on a scale of political distrust from 0 to 1 . While this coefficient size is small (considering also that the $\mathrm{SD}=0.13$ ), it can nevertheless be meaningful. Diffuse support is widely acknowledged to be stable and slow to change, unlike utilitarian support, and it is not expected to be as sensitive to institutional outputs. This indicates that internal migration from new member countries may have contributed to a slight rise in public distrust in the EU as predicted by Hypothesis 2, although I have some reservations regarding the robustness of this finding to certain sensitivity checks. There is more solid evidence that the size of this effect is dependent on the level of unemployment in a country, and as Figure 5 illustrates, if the unemployament rate is $10 \%$, the effect size doubles.

\subsection{Limitations}

Being an observational study, there are important limitations to be considered. First, owing to a lack of data availability, the observations are unbalanced, and the number of observations in this study is relatively low. To mitigate concerns about this, I have conducted a battery of robustness checks. First, I have conducted a series of drop-one country checks. I have also conducted a series of tests to verify that the results are not sensitive to interpolated values in 2012 and results are similar when re-running the analysis randomly allocating missing responses to the response categories. These estimates continue to support the substantive conclusions and further demonstrate that the results are not driven by measurement error or 


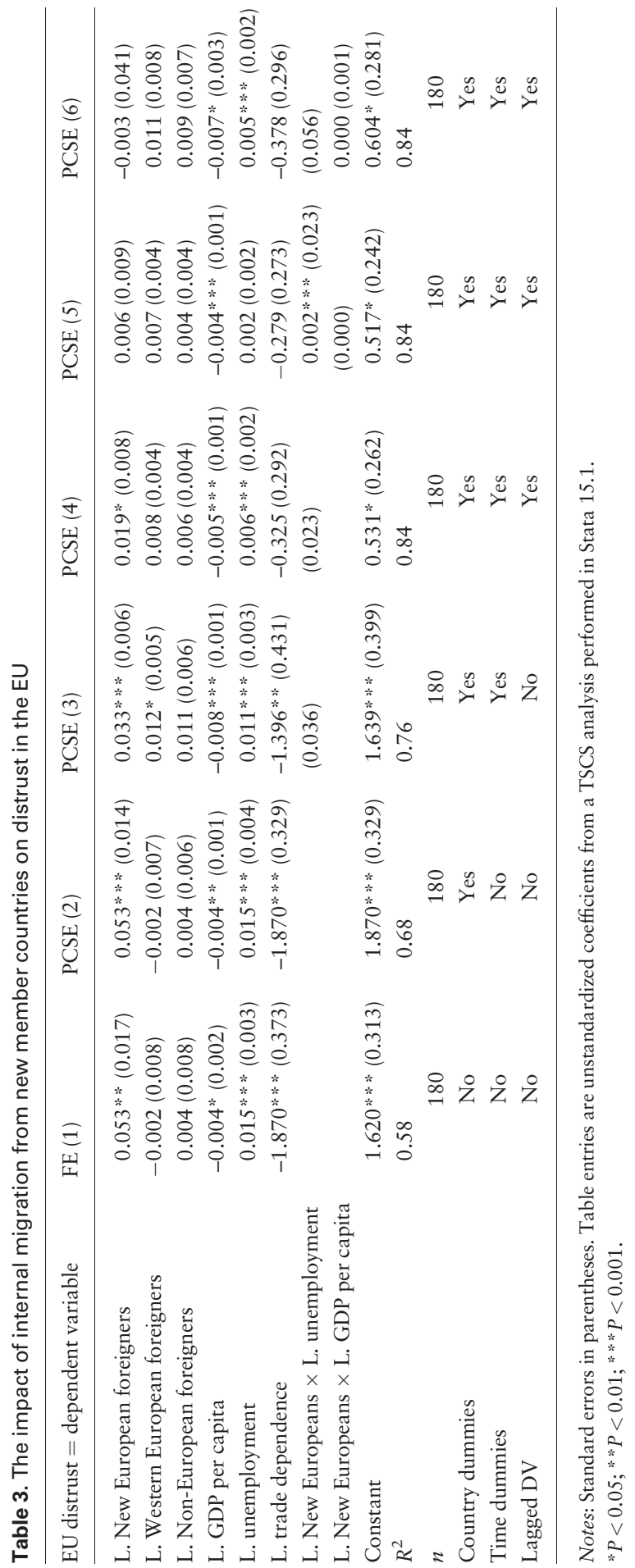




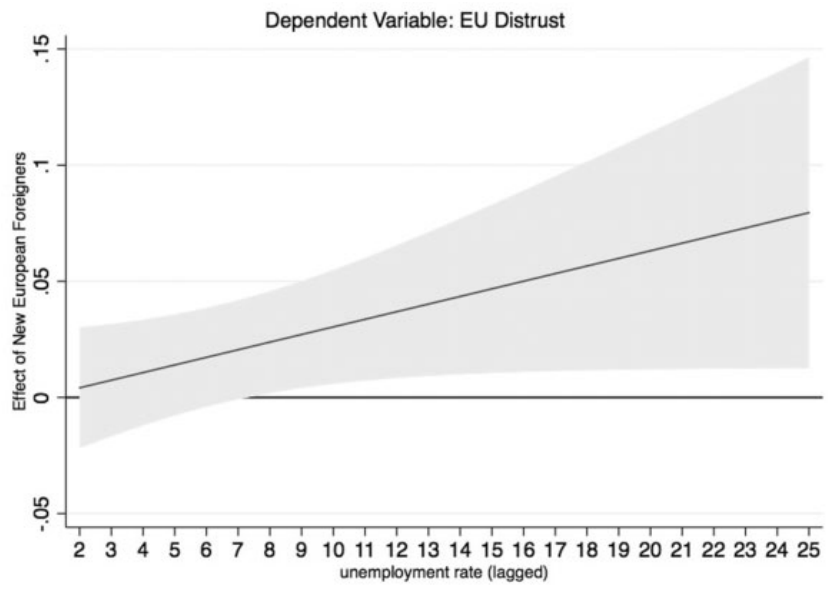

Figure 5. Effect of New European foreigners conditioned on levels of unemployment, EU mistrust.

other factors specific to a single country. Moreover, the small number of observations limits the full exploration of the dynamics between the variables required for a causal interpretation of the results, since this would result in a further loss of information. Still, as a robustness check, I have also tested a first differencing of the dependent variables and with different lag specifications. The findings corroborate that the positive relationship between internal migration from new member countries and mass support for EU membership is robust to these alternative specifications, while the relationship with mass distrust in the EU is not.

Another limitation of the study is that the results cannot offer causal evidence owing to the possibility of a reverse effect of EU attitudes and internal migration from new member countries. By lagging the independent variables, the design helps us discount this possibility by confirming the presence of Granger causality, whereby if variable $(\mathrm{X})$ causes variable $(\mathrm{Y})$, then a previous value of X should predict a subsequent value of Y (Granger, 1969). While Granger causality is not a proof of causality, it does suggest a temporal ordering that is consistent with a causal narrative. Nevertheless, with the data at hand, no design can perfectly resolve these causality issues. I cannot rule out that the presence of unobservable time variant characteristics could bias the results, namely that the distribution of citizens from new member countries in Western Europe is not random. It cannot be excluded, for instance, that the composition in the skill level of new Europeans may have shifted within countries over time. I have tried to rule out sources of potential endogeneity by testing possible confounding factors such as controlling for wage and inflation, and testing the models when first-differencing unemployment and GDP controls to take into consideration possible confounding economic changes which might have occurred during the period of the economic crisis. The full robustness checks are provided in Supplementary Appendix G.

\section{Discussion and conclusion}

This article argues that the explanatory power of group threat theory advances our understanding of how internal migration explains cross national differences in support for the EU 
and their changes over time. Using a TSCS research design, I examined mass opinion in 15 Western European countries from 1998 until 2014. Consistent with the hypothesis derived from the theory, the analysis identified a strong and positive relationship between the magnitude of migration from new European member countries and a greater public scepticism about the benefits of European membership in Western European countries. The results also reveal that this relationship is stronger when the economy is less prosperous. However, I find only weak evidence that internal migration is negatively related to mass distrust in European institutions, although the finding that the two are related during times of high unemployment is more robust.

The application of group threat theory adds theoretical nuance to the understanding of mass EU attitudes. These findings imply that public opinion internalizes internal migration as a threat to their group interest, which they perceive in terms of the nation state. Group threat theory offers theoretical insights into the possible mechanism for this relationship. Socio-tropic utilitarian orientations towards the nation state remain strong and thus an increase in foreigners, who represent members of an out-group, can be seen as a threat to the finite economic resources of the in-group. New European citizens who moved to live and work pose a particular economic threat compared to third country nationals as they have full rights of labour market participation and settlement. While individuals may lump EU and non-EU immigration together (McLaren, 2001) into a pot of grievances directed at the EU on the basis of uniformed perceptions of immigration, I find that a country's mass public opinion about the EU has distinctive reactions to internal EU migration versus immigration from outside the EU: the presence of European citizens from new member states is related to diminished public support for EU membership, while immigration from outside the European is not related to EU attitudes. When resources are more finite, this competition is in sharper relief, further diminishing support for membership in the EU.

Internal migration, particularly from new member countries, has become one of the most politicized aspects of the EU (Hurrelmann et al., 2015). Considering the findings of this study, free mobility paradigm may be at odds with the national sovereignty paradigm: internal migration can be perceived by the public as a threat to national sovereignty over borders, a function which Europeans have been socialized to believe belongs to the nation state. European integration has been an elite-driven project noted for its 'democratic deficit.' (Weiler et al., 1995) and this article joins others which highlight the political cost of continued expansion without the support of the polity (Favell and Hansen, 2002; Hobolt, 2014). By doing so, it contributes to an important scholarly debate about Euroskepticism and whether it has been triggered by recent events in Europe, such as the financial crisis or the refugee crisis. Contrary to previous studies that attribute eurosceptism to national identity and institutional factors (Serricchio et al., 2013; Ringlerova, 2015), these results joins a number of recent studies that support a utilitarian interpretation of eurosceptism that stresses the impact of contextual changes (Braun and Tausendpfund, 2014; Clements et al., 2014; Gomez, 2015; Harteveld et al., 2018).

It remains to be seen if the development in internal migration from new member countries will have temporary consequences or will give way to a gradual decline in mass support for Europe. Host societies do adapt to waves of newcomers over time (Alba, 1985; Ford, 2011) and so it is feasible that as the newness of EU workers from accession countries wears off, they will prompt less of a backlash. But this is also likely to depend on the extent to which new European citizens who work in Western Europe establish themselves in their 
host societies and are able to avoid the trap of temporary migration patterns (Ellerman, 2005).

This study assumes a structural view of public opinion and, thus, has not explored the mobilizing role of political actors or the tenor of the public discourse. Yet, shifts in public opinion should invariably raise questions about the environment from which the public draws its information, namely the role of the mass media. Future empirical attention should be given to how the valence of internal migration changed in the mass media after the new member countries accession and how EU citizens from new member countries have been portrayed across Western European media environments. It would be fruitful to test the impact of these different media frames on public opinion about the EU in an experimental setting. Such investigations will help us better understand the role of the media in the recent politicization of internal EU migration and what the political consequences are for EU.

\section{Supplementary material}

Supplementary material is available at Socio-Economic Review online.

\section{Acknowledgements}

The author will share all data for replication purposes. The author would like to thank the following persons for their comments and suggestions: Peter Kemp, Bernard Steunenberg, Tim Vlanas, Christine Jeannet and the participants of the panel 'Too Much is Too Much: Attitudes towards Europe' at the 2016 Annual Meeting of European Political Science Association.

\section{References}

Alba, R. D. (1985) Italian Americans: Into the Twilight of Ethnicity, Upper Saddle River, NJ, Prentice Hall PTR.

Almond, G. A. and Verba, S. (1965) The Civic Culture: Political Attitudes and Democracy in Five Nations, an Analytic Study, Boston, Little, Brown.

Anderson, B. (1983) Imagined Communities: Reflections on the Origin and Spread of Nationalism, London, New York, NY, Verso.

Anderson, C. J. (1998) 'When in Doubt, Use Proxies Attitudes toward Domestic Politics and Support for European Integration', Comparative Political Studies, 31, 569-601.

Anderson, C. J. and Reichert, M. S. (1995) 'Economic Benefits and Support for Membership in the E.U.: A Cross-National Analysis', Journal of Public Policy, 15, 231-249.

Beaudonnet, L. and Barbulescu, R. (2014) 'Protecting Us, Protecting Europe? Public Concern about Immigration and Declining Support for European Integration in Italy', Perspectives on European Politics and Society, 15, 216.

Beck, N. and Katz, J. N. (1995) 'What to Do (and Not to Do) with Time-Series Cross-Section Data', American Political Science Review, 89, 634-647.

Beck, N. and Katz, J. N. (1996) 'Nuisance vs. Substance: Specifying and Estimating Time-Series-Cross-Section Models', Political Analysis, 6, 1-36.

Blalock, H. M. (1967) Toward a Theory of Minority-Group Relations, New York, Wiley.

Blinder, S. and Jeannet, A. M. (2018) 'The 'Illegal' and the Skilled: Effects of Media Portrayals on Perceptions of Immigrants in Britain', Journal of Ethnic and Migration Studies, 44, 1444-1462. 
Blumer, H. (1958) 'Race Prejudice as a Sense of Group Position', The Pacific Sociological Review, $1,3-7$.

Bobo, L. and Hutchings, V. L. (1996) 'Perceptions of Racial Group Competition: Extending Blumer's Theory of Group Position to a Multiracial Social Context', American Sociological Review, 61, 951-972.

Boeri, T. and Brücker, H. (2005) 'Migration, Co-Ordination Failures and EU Enlargement' (SSRN Scholarly Paper No. ID 728963). Social Science Research Network, Rochester, NY.

Boomgaarden, H. G. et al. (2011) 'Mapping EU Attitudes: Conceptual and Empirical Dimensions of Euroscepticism and EU Support', European Union Politics, 12, 241-266.

Bovens, M. and Wille, A. (2008) 'Deciphering the Dutch Drop: Ten Explanations for Decreasing Political Trust in The Netherlands', International Review of Administrative Sciences, 74, 283-305.

Braun, D. and Tausendpfund, M. (2014) 'The Impact of the Euro Crisis on Citizens' Support for the European Union', Journal of European Integration, 36, 231-245.

Carey, S. (2002) 'Undivided Loyalties Is National Identity an Obstacle to European Integration?', European Union Politics, 3, 387-413.

Carrubba, C. J. (2001) 'The Electoral Connection in European Union Politics', The Journal of Politics, 63, 141-158.

Chang, L. W., Krosch, A. R. and Cikara, M. (2016) 'Effects of Intergroup Threat on Mind, Brain, and Behavior', Current Opinion in Psychology, 11, 69-73.

Ceobanu, A. M. and Escandell, X. (2010) 'Comparative Analyses of Public Attitudes toward Immigrants and Immigration Using Multinational Survey Data: A Review of Theories and Research', Annual Review of Sociology, 36, 309-328.

Citrin, J., Green, D., Muste, C. and Wong, C. (1997) 'Public Opinion toward Immigration Reform: The Role of Economic Motivations', The Journal of Politics, 59, 858-881.

Clements, B., Nanou, K. and Verney, S. (2014) 'We No Longer Love You, but We Don't Want to Leave You': The Eurozone Crisis and Popular Euroscepticism in Greece', Journal of European Integration, 36, 247-265.

Dancygier, R. M. (2010) Immigration and Conflict in Europe, Cambridge University Press.

Dancygier, R. M. and Donnelly, M. J. (2013) 'Sectoral Economies, Economic Contexts, and Attitudes toward Immigration', The Journal of Politics, 75, 17-35.

Duchesne, S. and Frognier, A.-P. (1994) 'Is There a European Identity?'. In Public Opinion and Institutionalized Governance, Oxford, Oxford University Press, pp. 193-226.

Easton, D. (1957) 'An Approach to the Analysis of Political Systems', World Politics, 9, 383-400.

Ellerman, D. (2005) 'Labour Migration: A Developmental Path or a Low-Level Trap?', Development in Practice, 15, 617-630.

Favell, A. and Hansen, R. (2002) 'Markets against Politics: Migration, EU Enlargement and the Idea of Europe', Journal of Ethnic and Migration Studies, 28, 581-601.

Fassmann, H. (2009) 'European Migration: Historical Overview and Statistical Problems', In Fassmann, H., Reeger, U. and Sievers, W. (eds) Statistics and Reality: Concepts and Measurements of Migration in Europe, Amsterdam, Amsterdam University Press, pp. 21-44.

Filindra, A. and Pearson-Merkowitz, S. (2013) 'Together in Good Times and Bad? How Economic Triggers Condition the Effects of Intergroup Threat', Social Science Quarterly, 94, 1328-1345.

Ford, R. (2011) 'Acceptable and Unacceptable Immigrants: How Opposition to Immigration in Britain Is Affected by Migrants' Region of Origin', Journal of Ethnic and Migration Studies, 37, 1017-1037.

Gabel, M. J. (1998) 'Economic Integration and Mass Politics: Market Liberalization and Public Attitudes in the European Union', American Journal of Political Science, 42, 936-953. 
Gabel, M. and Palmer, H. D. (1995) 'Understanding Variation in Public Support for European Integration', European Journal of Political Research, 27, 3-19.

Garry, J. and Tilley, J. (2009) 'The Macroeconomic Factors Conditioning the Impact of Identity on Attitudes towards the EU', European Union Politics, 10, 361-379.

Gellner, E. (1983) Nations and Nationalism, Ithaca, New York, Cornell University Press.

Golder, M. (2016) 'Far Right Parties in Europe', Annual Review of Political Science, 19, 477-497.

Gomez, R. (2015) 'The Economy Strikes Back: Support for the EU during the Great Recession', JCMS: Journal of Common Market Studies, 53, 577-592.

Gorodzeisky, A. (2011) 'Who Are the Europeans That Europeans Prefer? Economic Conditions and Exclusionary Views toward European Immigrants', International Journal of Comparative Sociology, 52, 100-113.

Granger, C. (1969) 'Investigating Causal Relations by Econometric Models and Cross-Spectral Methods', Econometrica, 37, 424-438.

Hadri, K. (2000) 'Testing for Stationarity in Heterogeneous Panel Data', The Econometrics Journal, 3, 148-161.

Harteveld, E. et al. (2018) 'Blaming Brussels? the Impact of (News about) the Refugee Crisis on Attitudes towards the EU and National Politics', JCMS: Journal of Common Market Studies, 56, 157-177.

Hetherington, M. J. (2004) Why Trust Matters: Declining Political Trust and the Demise of American Liberalism, New Jersey, Princeton University Press.

Hobolt, S. B. (2014) 'Ever Closer or Ever Wider? Public Attitudes towards Further Enlargement and Integration in the European Union', Journal of European Public Policy, 21, 664-680.

Hobolt, S. B. and Tilley, J. (2014) Blaming Europe?: Responsibility without Accountability in the European Union, Oxford, Oxford University Press.

Hobolt, S. B. and de Vries, C. E. (2016) 'Public Support for European Integration', Annual Review of Political Science, 19, 413-432.

Holland, D. et al. (2011) Labor Mobility within the EU: The impact of enlargement and the functioning of transitional arrangements, Comissioned By European Commission. London: National Institute of Economic and Social Research.

Hollifield, J., Martin, P. and Orrenius, P. (2014) Controlling Immigration: A Global Perspective, 3rd edn, California, USA, Stanford University Press.

Hooghe, L. and Marks, G. (2004) 'Does Identity or Economic Rationality Drive Public Opinion on European Integration?’, PS: Political Science \& Politics, 37, 415-420.

Hooghe, L. and Marks, G. (2005) 'Calculation, Community and Cues Public Opinion on European Integration', European Union Politics, 6, 419-443.

Hooghe, L. and Marks, G. (2009) 'A Postfunctionalist Theory of European Integration: From Permissive Consensus to Constraining Dissensus', British Journal of Political Science, 39, 1-23.

Höpner, M. and Jurczyk, B. (2015) How the Eurobarometer Blurs the Line between Research and Propaganda, MPIfG Discussion Paper 15/6, Cologne, Max Planck Institute for the Study of Societies.

Hurrelmann, A., Gora, A. and Wagner, A. (2015) 'The Politicization of European Integration: More than an Elite Affair?', Political Studies, 63, 43-59.

Huysmans, J. (2000) 'The European Union and the Securitization of Migration', JCMS: Journal of Common Market Studies, 38, 751-777.

Ipsos, M. O. R. I. (2016) 'Ipsos MORI | Poll | Immigration Is Now the Top Issue for Voters in the EU Referendum', accessed at https://www.ipsos-mori.com/researchpublications/researcharchive/ 3746/Immigration-is-now-the-top-issue-for-voters-in-the-EU-referendum.aspx on April 4, 2017.

Kaltenthaler, K. C. and Anderson, C. J. (2001) 'Europeans and Their Money: Explaining Public Support for the Common European Currency', European Journal of Political Research, 40, 139-170. 
Klingeren, M. V., Boomgaarden, H. G. and Vreese, C. H. D. (2013) 'Going Soft or Staying Soft: Have Identity Factors Become More Important than Economic Rationale When Explaining Euroscepticism?', Journal of European Integration, 35, 689-704.

Kumlin, S. (2009) 'Blaming Europe? Exploring the Variable Impact of National Public Service Dissatisfaction on EU Trust', Journal of European Social Policy, 19, 408-420.

Kumlin, S. (2011) 'Claiming Blame and Giving Credit? Unintended Effects of How Government and Opposition Frame the Europeanization of Welfare', European Union Politics, 12, 575-595.

Lahav, G. (2004) Immigration and Politics in the New Europe: Reinventing Borders, Cambridge/New York, NY, Cambridge University Press.

Luedtke, A. (2005) 'European Integration, Public Opinion and Immigration Policy Testing the Impact of National Identity', European Union Politics, 6, 83-112.

McLaren, L. (2007) 'Explaining Mass-Level Euroscepticism: Identity, Interests, and Institutional Distrust', Acta Politica, 42, 233-251.

McLaren, L. M. (2001) 'Immigration and the New Politics of Inclusion and Exclusion in the European Union: The Effect of Elites and the EU on Individual-Level Opinions regarding European and Non-European Immigrants', European Journal of Political Research, 39, 81-108.

McLaren, L. M. (2002) 'Public Support for the European Union: Cost/Benefit Analysis or Perceived Cultural Threat?', The Journal of Politics, 64, 551-566.

McLaren, L. M. (2004) 'Opposition to European Integration and Fear of Loss of National Identity: Debunking a Basic Assumption regarding Hostility to the Integration Project', European Journal of Political Research, 43, 895-912.

McLaren, L. M. (2006) Identity, Interests and Attitudes to European Integration, Basingstoke, United Kingdom, Palgrave Macmillan.

McLaren, L. M. (2012) 'The Cultural Divide in Europe: Migration, Multiculturalism, and Political Trust', World Politics, 64, 199-241.

Nissen, S. (2014) 'The Eurobarometer and the Process of European Integration', Quality \& Quantity, 48, 713-727.

Olzak, S. (1992) The Dynamics of Ethnic Competition and Conflict, California, USA, Stanford University Press.

Oorschot, W. J. H. v. (2000) 'Who Should Get What, and Why? on Deservingness Criteria and the Conditionality of Solidarity among the Public', Policy \& Politics, 28, 33-48.

Polavieja, J. G. (2016) 'Labour-Market Competition, Recession and Anti-Immigrant Sentiments in Europe: Occupational and Environmental Drivers of Competitive Threat', Socio-Economic Review,

Quillian, L. (1995) 'Prejudice as a Response to Perceived Group Threat: Population Composition and Anti-Immigrant and Racial Prejudice in Europe', American Sociological Review, 60, 586.

Ringlerova, Z. (2015) 'Weathering the Crisis: Evidence of Diffuse Support for the EU from a Six-Wave Dutch Panel', European Union Politics, 16, 558-576.

Risse, T. (2003) 'The Euro between National and European Identity', Journal of European Public Policy, 10, 487-505.

Risse, T. (2014) 'No Demos? Identities and Public Spheres in the Euro Crisis', JCMS: Journal of Common Market Studies, 52, 1207-1215.

Scheuer, A. (1999) 'A Political Community?'. In Schmitt, H. and Thomassen, J. J. A. (eds) Political Representation and Legitimacy in the European Union, Oxford, Oxford University Press, pp. 25-46.

Scheuer, A. and Schmitt, H. (2009) 'Dynamics in European Political Identity', Journal of European Integration, 31, 551-568. 
Schlipphak, B. and Treib, O. (2017) 'Playing the Blame Game on Brussels: The Domestic Political Effects of EU Interventions against Democratic Backsliding', Journal of European Public Policy, 24, 352-365.

Sears, D. and Funk, C. (1990) 'Self-Interest in American Political Opinions'. In Jane, M. (ed) Beyond Self-Interest, Chicago, Chicago University Press.

Serricchio, F., Tsakatika, M. and Quaglia, L. (2013) 'Euroscepticism and the Global Financial Crisis', JCMS: Journal of Common Market Studies, 51, 51-64.

Shaver, K. G. (1985) The Attribution of Blame: Causality, Responsibility, and Blameworthiness, Berlin, Germany, Springer-Verlag.

Sniderman, P. M., Peri, P. and Piazza, T. (2002) The Outsider: Prejudice and Politics in Italy, New Jersey, Princeton University Press.

Steinhardt, M. F. (2009) 'The Dimensions and Effects of EU Labour Migration in Germany'. In Galgóczi, B., Leschke, J. and Watt, A. (eds) EU Labour Migration since Enlargement, Ashgate, Surrey. pp.101-125.

Stimson, J. A. (1999) Public Opinion in America: Moods, Cycles, and Swings, Colorado, USA, Westview Press.

Taber, C. (2003) 'Information Processing and Public Opinion'. In Sears, D. O., Huddy, L., and Jervis, R. (eds) Oxford Handbook of Political Psychology, USA, Oxford University Press, pp. 433-476.

Tajfel, H. (1982) 'Social Psychology of Intergroup Relations', Annual Review of Psychology, 33, $1-39$.

Toshkov, D. and Kortenska, E. (2015) 'Does Immigration Undermine Public Support for Integration in the European Union?', JCMS: Journal of Common Market Studies, 53, 910-925. van Klingeren, M., Boomgaarden, H. G. and de Vreese, C. H. (2017) 'Will Conflict Tear Us apart? the Effects of Conflict and Valenced Media Messages on Polarizing Attitudes toward EU Immigration and Border Control', Public Opinion Quarterly, 81, 543-563.

Vasilopoulou, S., Halikiopoulou, D. and Exadaktylos, T. (2014) 'Greece in Crisis: Austerity, Populism and the Politics of Blame', JCMS: Journal of Common Market Studies, 52, 388-402.

de Vreese, C. H. and Boomgaarden, H. G. (2005) 'Projecting EU Referendums', European Union Politics, 6, 59-82.

Weiler, J. H. H., Haltern, U. R. and Mayer, F. C. (1995) 'European Democracy and Its Critique', West European Politics, 18, 4-39. 